\title{
An Utilization of Palm Fuel Ash (POFA) and Ceramic Waste as Cement Materials Replacement in Concrete Production
}

\author{
Faisal Sheikh Khalid ${ }^{1}$, Puteri Natasya Mazenan ${ }^{1}$, Abdul Halim Abdul Ghani ${ }^{1}$, Nurul Bazilah Azmi ${ }^{1}$, Mohd Irwan \\ Juki $^{1}$, Shahiron Shahidan ${ }^{1}$, Mohd Haziman Wan Ibrahim ${ }^{1}$ \\ ${ }^{1}$ Jamilus Research Center, Faculty of Civil and Environmental Engineering, Universiti Tun Hussein Onn Malaysia, Batu Pahat, Johor, \\ Malaysia \\ *Corresponding author E-mail: faisalsh@uthm.edu.my
}

\begin{abstract}
The consumption of agricultural and industrial wastes has grown rapidly across the world which leads to create large quantities of wastes. It reflects the problem of having a limited number of landfills due to a huge amount of waste produced. Therefore, the solution is recycle the agricultural and industrial wastes as one of the materials use in concrete. Agricultural and industrial wastes were selected as cement replacement in a concrete production. This study aims to investigate the concrete properties containing palm oil fuel ash (POFA) and ceramic tile wastes, such as workability, compressive and splitting tensile strength. The concrete mix design ratio was designed for concrete grade strength 30 and water cement ratio of 0.55. Testing for compressive strength was measured at 7 and 28 days and for tensile strength only at 28 days. This research finds that with combination of 5\% POFA and $10 \%$ ceramic with $27.1 \mathrm{MPa}$ for compressive strength and 2.5 MPa for tensile strength will be the optimum mix design to replace cement in concrete. This research helps to improve the knowledge, increase the level of environmental awareness and understanding the importance and recycling the construction waste generated.
\end{abstract}

Keywords: cement replacement; ceramic tiles waste; concrete; palm oil fuel ash (POFA), strength

\section{Introduction}

Concrete is very costly according to market prices. Many researchers are studying on how to reduce the cost of concrete and make it more economical. One of the best ways is replacing the concrete with cheaper materials such as agriculture or ceramic wastes. Currently, the increasing interest in the environmental issue is pressuring the industry player to develop products and materials that are more environmentally friendly. In this study, the agriculture waste which is palm oil fuel ash (POFA) and ceramic from industrial wastes were used as cement replacement in concrete production.

Palm oil industry is one of the major agro-industries in Malaysia and Thailand where a large amount of waste in the forms of empty fruit bunches, fibers and kernel was produced in this industry [1$3]$. Usually this product is used as fuel to heat up boiler for generation of electricity in palm oil factories [4]. The combustion process of palm oil husk and palm kernel shell in the steam boiler will produce palm oil fuel ash (POFA) [5]. Sooraj (2013) [6] studied the effects of palm oil fuel ash (POFA) on strength properties of concrete where the discussed about the strength properties of POFA concrete with different replacement level and compared with the control mixture. The replacement level of POFA are $10 \%$, $20 \%, 30 \%$ and $40 \%$ with 0.45 of water-cement ratio. It shows that POFA can be used as an alternative cement because of the excellent properties for pozzolanic material replacement in concrete. For a good strength, the author recommended that the optimum replacement level of OPC by POFA is $20 \%$. POFA has been introduced to produce the lightweight foamed concrete for non- structural building material used [7]. It has been conducted by replacing $10 \%, 20 \%, 30 \%, 40 \%$ and $50 \%$ of POFA and the results indicated the potential of POFA in foamed concrete production. The results show that the foamed concrete with 20\% POFA substitution is still applicable for non-structural building element such as concrete block for non-bearing wall. A utilization of agriculture wastes has been implemented as partial replacement of fine aggregates in concrete [8]. Considering the facts, an experimental study was conducted to find out the potential usage of palm oil fibers (POB) in concrete. The flexural strength of concrete was noticed in the range of $2.25 \mathrm{MPa}$ and $2.29 \mathrm{MPa}$, whereas, the higher value of flexural strength was recorded. Hence, these results show that the strength performances of concrete containing POB clinker could be improved with the addition of polypropylene fibre.

Awal et al. (2011) [9] conducted study on the properties of concrete containing high volume palm oil fuel ash as cement replacement. POFA replaced the cement with 50\%, 60\% and 70\% in the concrete specimens and were made at various water-cement ratios of $0.38,0.42$ and 0.48 with super plasticizer content of up to $2 \%$. Workability in terms of slump and the strength properties were studied and compared with concrete containing 100\% OPC as control. Alsubari et al. (2016) [10] studied on the utilization of high-volume treated palm oil fuel ash to produce sustainable selfcompacting. This study was conducted to evaluate the use of highvolume treated palm oil fuel ash (T-POFA) in producing economical and eco-friendly self-compacting concrete (SCC) on laboratory investigations. The concrete mixtures were prepared with $0 \%$, $50 \%, 60 \%$ and $70 \%$ of T-POFA to replace OPC at a constant water-cement ratio of 0.35 . Self-Compatibility testing methods were also employed to evaluate the fresh properties of SCC. The best 
results to use T-POFA as a cement replacement up to $70 \%$ in SCC to produce low-cost and sustainable concrete.

Azmi et al. (2017) [11] studied on the use of waste ceramic tile in cement production. The author focused on the usage of waste tile as aggregate material. Percent of replacement have been used in this study was at $25 \%, 35 \%$ and $45 \%$ of the RCA and 5\%, $10 \%$ and $15 \%$ for ceramic, respectively. Furthermore, this research was conducted to find the optimum percentage of aggregate replacement, using water-cement ratio of 0.55 with concrete grade $25 / 30$. The best percentage of replacement was the RCA35\% C15\% with the compressive strength of $34.72 \mathrm{MPa}$ and the water absorption was satisfied. Luiz et al. (2012) [4] used glass and red-clay ceramic waste as cement mortars components. The compressive strength activity at 7,28 and 90 days, was determined in mortars produced that is each finely grinded waste ceramics and different percentages of partial cement replacement. Tavakoli (2013) [13] studied the properties of concretes produced with waste ceramic tile aggregate. The author focused on the investigation of possibility of using waste ceramic tile in concrete. The characteristics of ceramic aggregate were measured and grinded to use in concrete as the replacement for coarse aggregates with $0 \%$ to $40 \%$ and $0 \%$ to $100 \%$. The results showed the increases in compressive strength, but also a decrease in unit weight.

The aim of this study is to investigate a material replacement in the concrete by using the agricultural and ceramic waste as partial cement replacement materials. The objective is to investigate the workability, compressive, tensile strength and determine the optimum mix design of concrete containing combination of POFA and ceramic wastes as cement replacement materials.

\section{Materials and Method}

Material preparation is the most important stage in the concrete production. Quality of materials used in concrete mixture is one of the main factors in determining the concrete strength. Then, the suitable concrete mix design was calculated before casting the concrete. Next, specimen was tested according to the concrete mix design. All tests were conducted by following the available code of practice.

\subsection{Preparation of Materials}

POFA is a product that produced in palm oil mill. Palm oil fuel ash used in this study as the cement replacement materials in the concrete mixtures. The POFA content in the mix proportions were $5 \%, 10 \%$ and $15 \%$. For the ceramic waste materials were taken from the tile ceramic factory. In this study, the ceramic wastes content to replace the cement contains was $5 \%, 10 \%$, and $15 \%$. The ceramic waste was grinded by using grinder until the particle size of the ceramic close enough to cement size particle. Figure 1 shows ceramic waste materials and palm oil fuel ash (POFA) materials.

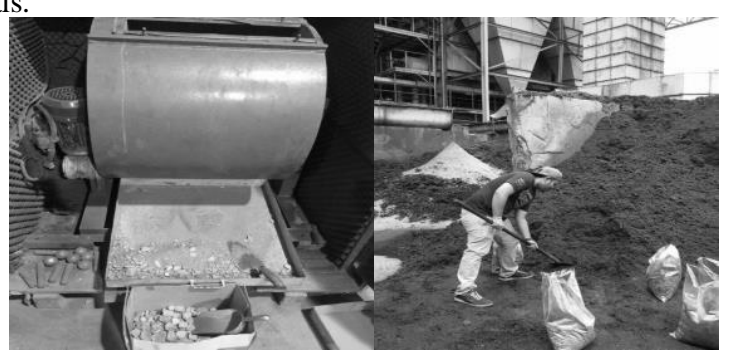

Fig. 1: (a) Ceramic waste materials and (b) Palm oil fuel ash (POFA).

\subsection{Methods of Preparing Sample}

The cube mold with size $100 \times 100 \times 100 \mathrm{~mm}$ was prepared for the compression strength test. All cube specimens are stored in a water tank to cure the specimens for 7 and 28 days. For the cylinders mold with a diameter of $100 \mathrm{~mm}$ and a height of $200 \mathrm{~mm}$ was prepared for the splitting tensile strength test. The molds were filled to the top with the compaction. All the cylinders were stored in a water tank to cure the specimens for 28 days. This study was conducted by using 0.55 water cement ratio. The OPC was replaced by POFA and ceramic wastes at $5 \%, 10 \%$ and $15 \%$. For curing process, the concrete cylinder was soaked in water for a certain period which is 28 days and this activity is called curing. The curing process is conducted to control the moisture content of the concrete cylinder during the hardening process.

\subsection{Testing Method}

There are several tests that needs to be conducted in determining the properties of material used in this study. The mix was tested for slump test, compressive and splitting tensile strength tests. Slump test was conducted to determine the workability of the concrete mix by following the standard as stated in ASTM 143-12. The compressive strength of hardened-state concrete is determined according to EN12390 - 3:2009 (2009). The compressive strength of the concrete cube was tested at 7 and 28 days age of curing. The average of three test results for each batch was taken. The cubes were tested using a hydraulic compression test machine with $2000 \mathrm{kN}$ capacity. Tensile strength bearing strips are placed at the top and bottom of the specimens to ensure the specimen in straight condition. The load is applied using a hydraulic compression tester and universal testing machine at $0.1 \mathrm{kN} / \mathrm{s}$.

\section{Results and Discussions}

Result from the study found that there are slight differences on the strength of concrete between normal concrete and the concrete containing POFA and ceramic waste as cement replacement materials.

\subsection{Slump of Concrete}

From Table 1 the slump for the normal concrete is $70.0 \mathrm{~mm}$ which it in the medium range of workability of concrete. Meanwhile, the concrete containing POFA and ceramic waste slump value is variant in $\mathrm{mm}$ but still have the workability which is still in the range. The workability of the concrete is less than the control due to the POFA which absorbing water and drying the concrete mixture and decrease the slump value compared to the normal concrete. When the number of the POFA increase, the slump reading will be lower compared to the concrete mix which contain less POFA.

Table 1: Comparison slump results between normal concrete and concrete containing POFA and ceramic wastes.

\begin{tabular}{|c|c|c|}
\hline Type of concrete & Slump reading(mm) & Type of slump \\
\hline Normal concrete & 70.0 & True \\
\hline POFA 5\% - Ceramic 5\% & 65.2 & True \\
\hline POFA 5\% - Ceramic 10\% & 64.8 & True \\
\hline POFA 5\% - Ceramic 15\% & 65.3 & True \\
\hline POFA 10\% - Ceramic 5\% & 56.3 & True \\
\hline POFA 10\% - Ceramic 10\% & 59.4 & True \\
\hline POFA 10\% - Ceramic 15\% & 53.7 & True \\
\hline POFA 15\% - Ceramic 5\% & 45.6 & True \\
\hline POFA 15\% - Ceramic 10\% & 3.0 & Zero \\
\hline POFA 15\% - Ceramic 15\% & 3.0 & Zero \\
\hline
\end{tabular}

\subsection{Density of Concrete}

From Figure 2, the control concrete which normal concrete have a $2.1 \mathrm{~kg} / \mathrm{m}^{3}$ of concrete density, for first batch which is P5/C5, $\mathrm{P} 5 / \mathrm{C} 10$ and $\mathrm{P} 5 / \mathrm{C} 15$, the density average is around $2.2 \mathrm{~kg} / \mathrm{m}^{3}$. It is higher than the density of control concrete. The second batch of concrete which is $\mathrm{P} 10 / \mathrm{C} 5, \mathrm{P} 10 / \mathrm{C} 10$ and $\mathrm{P} 5 / \mathrm{C} 15$ density are 2.2 $\mathrm{kg} / \mathrm{m}^{3}$ in average, same with the first batch. The last batch which is $\mathrm{P} 15 / \mathrm{C} 5, \mathrm{P} 15 / \mathrm{C} 10$ and $\mathrm{P} 15 / \mathrm{C} 15$, the concrete density is average at $2.2 \mathrm{~kg} / \mathrm{m}^{3}$. The physical properties of POFA and ceramic is a 
fine material that replacing the cement can cause of the density of concrete containing POFA and ceramic waste increase in this study. It is similar findings as claimed by Shahidan et al. (2017) [13] that due to the specific gravity of materials is higher compared to the ordinary Portland cement.

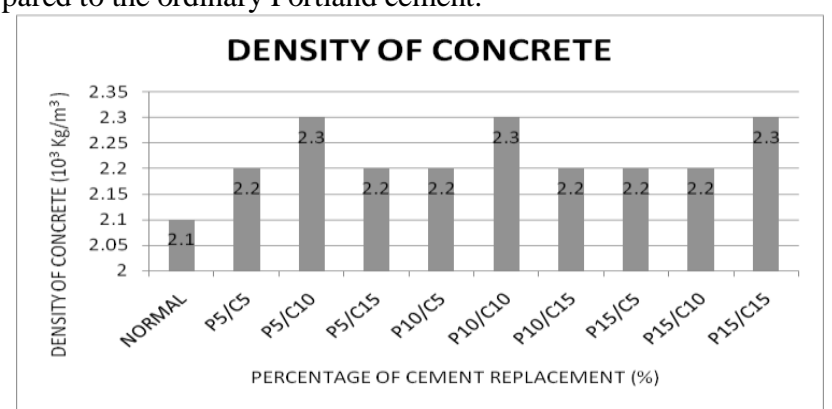

Fig. 2: Density for normal concrete and concrete containing POFA and ceramic waste.

\subsection{Compressive Strength Test}

The compressive strength of normal concrete and concrete containing POFA and ceramic waste are shown in Figure 3. For 7 days of compressive strength, we can clearly see there is 3 batches of concrete. For the first batch, the graph pattern is ascending and decreasing form, which is the strength for the concrete containing $5 \%$ POFA and $5 \%$ of ceramic waste was $18.3 \mathrm{MPa}$ and the second proportion is containing $10 \%$ ceramic waste which showing the increasing in compressive strength about $5.5 \%$ difference from the first proportion.

For the second batch, it can be summarized that the strength decrease when the number of the ceramic increase. The highest compressive strength for the second group is $21.2 \mathrm{MPa}$ and the lowest strength in the second group is about $24.1 \%$. For the third batch, it is clearly shown the strength is decrease when the percentage of the ceramic waste is increase. The highest value for the third group is 19.3 MPa and the lowest is about 17.5 MPa gives $9.3 \%$ difference.

For 28 days of curing age, the highest compressive strength of concrete is the concrete containing 5\% of POFA and 10\% of ceramic waste with the strength is $27.1 \mathrm{MPa}$ and the lowest compressive strength is concrete containing 5\% of POFA and 15\% of ceramic waste, the compressive strength is $18.5 \mathrm{MPa}$ at 28th days. For the first batch, the graph pattern is fluctuated, which the strength for the concrete containing 5\% POFA and 5\% of ceramic waste was $26.9 \mathrm{MPa}$. From Figure 3, it can be summarized that the strength is decrease when the number of the ceramic increase. The highest compressive strength for the second batch is $26.5 \mathrm{MPa}$ and the lowest strength in the second batch is $25.5 \mathrm{MPa}$. For the third batch, the strength is decrease and then increase when the percentage of the ceramic waste is increase. The highest value for the third group is $25.5 \mathrm{MPa}$ and the lowest is about 22.4 MPa gives $12.2 \%$ differences. This value can be accepted for non-structural components such as partition wall, concrete block and decorative block can be made from these mixtures $[14,15]$.

From the result above, we can see that the highest difference percentages are the concrete contain 5\% POFA and $15 \%$ ceramic waste with the differences $43.2 \%$. While the smallest difference percentage and the nearest value of compressive strength with the normal concrete is concrete with 5\% POFA and $10 \%$ ceramic waste with the differences about $2.5 \%$. This means the smallest differences is the suitable percentage of cement replacement in this study [16].

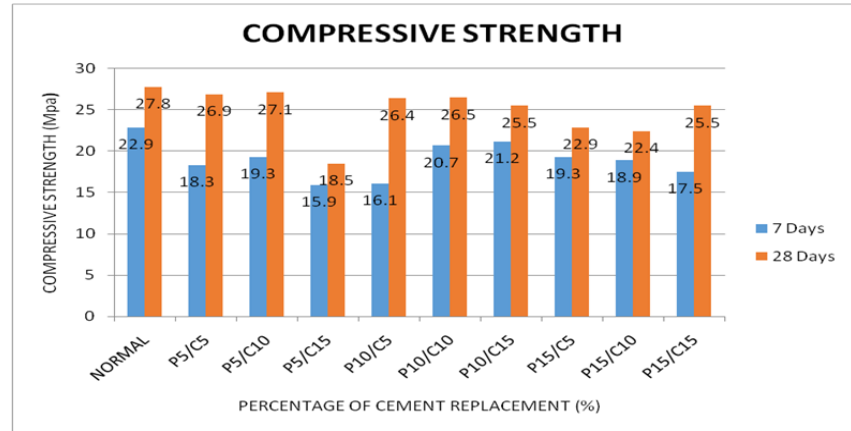

Fig. 3: Compressive strength for normal concrete and concrete containing POFA and ceramic waste.

\subsection{Tensile Strength Test}

Figure 4 indicates the tensile strength of concrete. There are 3 batches of concrete. It clearly shows that the strength pattern changes across the increment of replacement contents.

For the first batch the strength is ascending then decreasing when the percentage of ceramic waste is increase. For the second batch, the pattern seems descending when the ceramic percentage is increasing. For the third batch, the strength is decreasing when the percentage of the ceramic is increase. An overall pattern in this study concluded that the more percentage of ceramic replacement contents, the tensile strength of the concrete tends to decrease, while the increase percentage of POFA caused the concrete tensile strength increase.

The highest tensile strength of concrete for 28th days is the concrete containing 5\% of POFA and $10 \%$ of ceramic waste with the strength is $2.50 \mathrm{MPa}$ with the difference with $0 \%$ to the normal concrete in this study and the lowest tensile strength is concrete containing $10 \%$ of POFA and $15 \%$ of ceramic waste. The compressive strength is $1.49 \mathrm{MPa}$ at 28th days is difference with the normal concrete which is $40.4 \%$ lower and the nearest tensile strength to the normal concrete is also be the highest value of tensile strength which is concrete containing 5\% POFA and 10\% of ceramic waste with the strength of concrete is $2.50 \mathrm{MPa}$, with $0 \%$ difference percentage to the normal concrete. That means this proportion is the most suitable percentage can be used as the cement replacement for the tensile strength [16].

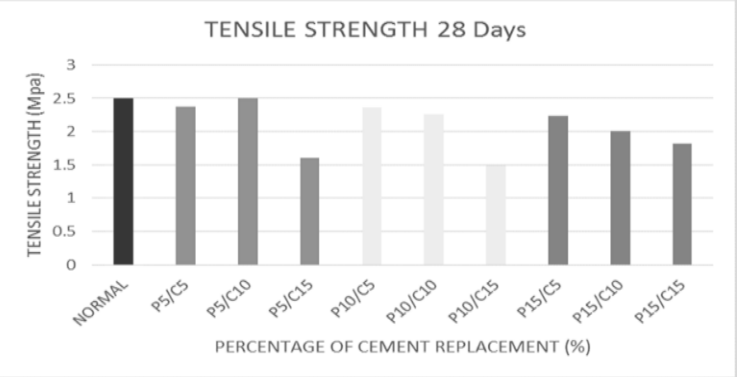

Fig. 4: Result of the splitting tensile test for concrete containing POFA and ceramic waste.

\section{Conclusion}

The highest compressive strength of concrete for 28th days is the concrete containing 5\% of POFA and 10\% of ceramic waste with the strength is $27.1 \mathrm{MPa}$ with the difference with the normal concrete about $2.5 \%$ higher than the normal concrete in this study and the nearest compressive strength to the normal concrete which means this proportion is the most suitable percentage can be used as the cement replacement in this study in term of compression. For splitting tensile test, the highest tensile strength of concrete for 28th days is the concrete containing 5\% of POFA and $10 \%$ of ceramic waste with the strength is $2.50 \mathrm{MPa}$ same with the strength of normal concrete. It means that this proportion is the 
most suitable percentage can be used as the cement replacement in this study in term of tensile strength. Based on the compression and tensile results, it can be concluded that the most suitable proportion for both mechanical properties is the concrete contain 5\% POFA and $10 \%$ ceramic waste. This value can be accepted for non-structural components such as partition wall, concrete block and decorative block can be made from these mixtures.

\section{Acknowledgement}

This work was financially supported by University Tun Hussein Onn Malaysia (UTHM) and Minister of Education Malaysia (KPM) through Dana Pembudayaan penyelidikan (RAGS) Vot. No. R-058.

\section{References}

[1] Bullard JW, Jennings HM, Livingston RA, Nonat A, Scherer GW Schweitzer JS, Scrivener KL and Thomas JJ, "Mechanisms of cement hydration," Cement and Concrete Research, Vol. 41, No.12, (2011), pp 1208-1223.

[2] Daniyal M and Ahmad S, "Application of Waste Ceramic Tile Aggregates in Concrete," International Journal of Innovative Research in Science, Engineering and Technology, Vol. 4, No. 12, (2015), pp 12808-12815.

[3] Leman AS, Shahidan S, Nasir AJ, Senin MS, Mohd Zuki SS, Wan Ibrahim MH, Deraman R, Khalid FS and Azhar ATS, "Properties of concrete containing coconut shell powder (CSP) as a filler" IOP Conf. Series: Materials Science and Engineering, Vol. 271, (2017), 012006.

[4] Luiz Castro-gomes A, Pereira-de-oliveira JP, and Santos PMS "The potential pozzolanic activity of glass and red-clay ceramic waste as cement mortars components," Construction and Building Materials, Vol. 31, (2012), pp 197-203.

[5] Mazenan PN, Khalid FS, Shahidan S, and Shamsuddin S, "Review of palm oil fuel ash and ceramic waste in the production of concrete" IOP Conf. Series: Materials Science and Engineering, Vol. 271, (2017), 012051

[6] Sooraj VM, "Effect of palm oil fuel ash (POFA) on strength properties of concrete." International Journal of Scientific and Research Publications, Vol 3, No. 6, (2013), pp 1-7.

[7] Munir A, Abdullah, Huzaim, Sofyan, Irfandi, \& Safwan, "Utilization of palm oil fuel ash (POFA) in producing lightweight foamed concrete for non-structural building material", Procedia Engineering, Vol. 125, (2015), pp. 735-746.

[8] Wan Ibrahim MH, Sajjad Ali Mangi, Burhanudin MK, Ridzuan MB, Jamaluddin N, Shahidan S, Wong YH, Faisal SK, Fadzil MA, Ramadhansyah PJ, Ayop SS and Othman NH, "Compressive and flexural strength of concrete containing palm oil biomass clinker and polypropylenefibres" IOP Conf. Series: Materials Science and Engineering, Vol. 271, (2017), 012011.

[9] Awal ASMA and Abubakar SI, "Properties of concrete containing high volume palm oil fuel ash: a short-term investigation," Malaysian Journal of Civil Engineering, Vol. 3, No. 2, (2011), pp 164176.

[10] Alsubari B, Shafigh P, and Jumaat MZ, "Utilization of high-volume treated palm oil fuel ash to produce sustainable self-compacting concrete" Journal of Cleaner Production, Vol. 137, (2016), pp 982 996.

[11] Azmi NB, Khalid FS, Irwan JM, Anting N and Mazenan PN “A study on the performance of concrete containing recycled aggregates and ceramic as materials replacement," IOP Conf. Series: Materials Science and Engineering, Vol. 271, (2017), 012081.

[12] Tavakoli D, Heidari A, Karimian M, \& Branch N, "Properties of concretes produced with waste", Asian Journal of Civil Engineering Vol. 14, No. 3, (2013), 369-382.

[13] Shahidan S, Tayeh BA, Jamaludin AA, Bahari NAAS, Mohd Zuki SS, Ali N and Khalid FS, "Physical and mechanical properties of self-compacting concrete containing superplasticizer and metakaolin", IOP Conf. Series: Materials Science and Engineering, Vol. 271, (2017), 132575.

[14] Anuar M A M, Anting N, Shahidan S, Lee Y Y, Md Din M F, Khalid F S and Nazri W M H W "Preliminary evaluation of physical and chemical characterization of waste palm oil shell as cool material replaced in asphaltic concrete as fine aggregate", IOP Conf.
Series: Materials Science and Engineering, Vol. 271, (2017), 012054.

[15] Shahidan S, Abdul Kadir A, Yee L, Ramzi N I R and Sheikh F "Preliminary evaluation of physical and chemical charac-terization of waste palm oil shell as cool material replaced in asphaltic concrete as fine aggregate", MATEC Web of Conferences, Vol. 103 (2017), 01020 .

[16] Leman A S, Shahidan S, Senin M S, Shamsuddin S M, Anak Guntor N A, Mohd Zuki S S, Khalid F S, Azhar A T S and Razak N H $\mathrm{S}$ "Durability of coconut shell powder (CSP) concrete", IOP Conf. Series: Materials Science and Engineering, Vol. 271, (2017), 012007. 